good deal in the novel of the Emperor Valentinian being at Rome. History seems to show that he never was there. Nor was Ausonius. Claudian too seems not to have appeared in Rome till about a quarter of a century after Mr. Perry's characters quote him. Indeed I am not clear that Valentinian was even Emperor at all when Paula married. Let the author have the benefit of the doubt.

Ammianus laughs at the Roman fancy for new-fangled names, citing or inventing Reburrus. Cinara (one of Paula's Horatian maids) points out Marius Maecius Maemius Furius Balburius Caecilianus Placidus, who is happily shortened to 'Marius Maecius etcetera.' The menu at the marriage suggests the first rather than the fourth century. Mr. Perry quotes Macrobius on fourth century feasting, so that it is odd that Paula's family should go back to the Satirists. It is indeed a 'dubious feast' (p. 91). The 'ball' too, is rather indeterminate; is it British, or does it lean to Herodias' daughter and the ambubaiae? I do not think either would have won Damasus' blessing. 'Patrician' is a word of various meanings-it means one thing in early Roman history, another in Gibbon, and a third-let us sayin Disraeli; what it means in this book, 1 do not know. Nor do I know any authority for the statement (p. 15) that the 'common herd of plebeians,' the 'colluvies gentium, 'could still bestow consulships, provinces: and legions.' Nor am I clear as to Toxotius real feelings when his wife 'put off the toga praetextata of maidenhood and assumed the toga recta of the married woman'? (p. 99).

Turning to the other side of the book one may ask, will it do as a novel? It is full of Latin quotations-odd enough, some of them ("all the various noises that went tc make up the strepitumque Romae"- p. 78)and I incline to think that these will mili. tate against its success with any class of readers to whom the character-drawing and dialogue might appeal.

\title{
CORRESPONDEENCE.
}

\section{LATIN AND THE UNIVERSITY OF BIRMINGHAM.}

'Latin [it is true] is an optional subject for matriculation at the University last founded in England.' This statement, made in the July number of the Classical Review of the present year, though true so far as it goes, nevertheless requires to be supplemented, if it is to represent accurately the situation in the University of Birmingham. Latin is an optional subject for matriculation in the Faculties of Science and Conmerce at Birmingham, but not for matriculation in the Faculties of Arts and Medicine. In other words, Arts students and Medical students must pass in Latin at the Birmingham matriculation examination, but Science and Commerce students need not. The Birmingham solution of the question of Latin at the matriculation depends, therefore, on faculty differentiation; what is requisite as a preparation for a University course in one line of study is not, it is held, necessarily requisite for all lines of study. And in basing its scheme on the requirements of the several Faculties of the University, Birmingham at the same time recognises that there exist and should exist many different types of schools from which the
University may hope to draw students. A the recent matriculation examination, how ever, of 115 candidates over 100 offerec Latin as one of their two foreign languages.

$A$ word may be added on the charactel of the examination in Latin at the Birming ham matriculation. Each candidate has ti offer a set book chosen by himself (subject to the approval of the University); but the examination on this set book is conducter viva voce. The written examination i: limited to translation at sight, grammar and composition. In this way, it is hoped the difficulties connected with set books maj be to sume extent avoided; though, at thi same time, the University has to face thi new difficulty of examining all candidate: viva voce-a difficulty which in the case o a University with a very large number 0 candidates for matriculation might provi insurmountable. But at any rate the Birmingham method of dealing with thi: question avoids embarrassing schools by prescribing a single book which they mus all read, however unsuitable it may happes to be to the class in which it is studied and it also avoids the peril of abolishing se 
books altogether and so jeopardizing the literary element in classical study. The passages set for unseen translation are not all of them taken from classical authors. By setting (among other passages) one which has been specially written for the purpose of the examination, it is possible to provide a really easy piece of Latin, failure to translate which implies ignorance of the very elements of the language; and such passages may moreover be multiplied ad infinitum, so that there will be no difficulty in providing easy passages which are ' unseen' in fact as well as in name; whereas, if unseens had always to be taken from classical authors the stock of really easy passages would ultimately become exhausted, as was pointed out in the Classical Review. No doubt many scholars object to modern Latin, even though written in a classical style; but they may be willing to waive their objections in view of the positive advantage possessed by passages written or adapted $a d$ hoc-viz. simplicity or just such a degree of difficulty as is desired for the purpose of the examination.

\section{E. A. Sonnenschein.}

[We gladly insert Professor. Sonnenschein's interesting communication. The remarks, however, which are quoted at the beginning of his letter were not intended to be a complete definition of the place of Latin in the matriculation scheme of Birmingham University, for which purpose they were of course inadequate, but to serve as part of a proof that the ancient languages were losing their commanding position of former days.

Since they were written, there have been more signs of the times. Latin is no longer a compulsory subject for eadetships in the Royal Navy, and Oxford is to be asked in the present term to make Greek optional in Responsions.-Eb. C.R.]

\section{A R C H A E OLOG Y.}

\section{THE GOLDEN BOUGH AND THE REX NEMORENSIS.}

The Golden Bough. A Study in Magic and Religion. By J. G. Frazer, D.C.L., LL.D., Litt.D. Second Edition, revised and enlarged. Vols. I.-III. Macmillan $\&$ Co. 1900. 36s. net.

Dr. Frazer's Golden Bough has grown apace. It now extends over three octavo volumes instead of the previous two. Nor is this all; for the thinnest of the new volumes is thicker than either of the old, and they are printed in a slightly smaller type with forty lines to a page instead of thirty-four. The second edition of the book is in fact considerably more than twice the size of the first. It may be worth while to suggest that, if a third edition is needed (and it will be), the long lists of customs and ceremonies on which the author bases his conclusions should be given, say, in brevier while the conclusions themselves are stated, as at present, in small pica. This would be doubly advantageous. It would save space. And it would enable-I will not say, the casual reader to skim the book-but the student, when he re-reads it, to pick out more readily the main lines of the argument.
Again, it is to be hoped that a future edition will be illustrated throughout. Illustrations in any work dealing with antbropological or ethnological questions are of real importance-a fact long since appreciated by the publishers of such periodicals as the Zeitschrift des Vereins für Volkskunde or L'Anthropologie or the Journal of the Anthropological Institute. Nor would it be difficult to get together typical representations of the various customs described in Dr. Frazer's work. Anthropologists and ethnologists rely for the most part on data supplied by ethnographers; and ethnographical books are nowadays almost always illustrated. Besides, folk-lore collections are springing up everywhere : museums, public and private, abound in objects of interest to the student of comparative religion. To give but a single instancethe one nearest to hand-our Cambridge Archaeological Museum possesses an interesting series of corn-mothers and corn-babies, including a beautifully plaited specimen from Greece originally obtained by $\mathrm{Mr}$. W. H. D. Rouse ${ }^{-1}$ and deposited by the Folk Lore Society in 1898, and a 'harvestmaiden' from Perth presented by Dr.

1 See Mr. Rouse's remarks in Folk-Lore vii. 147 and in his Gk. Votive Offerings p. 50, n. I. 